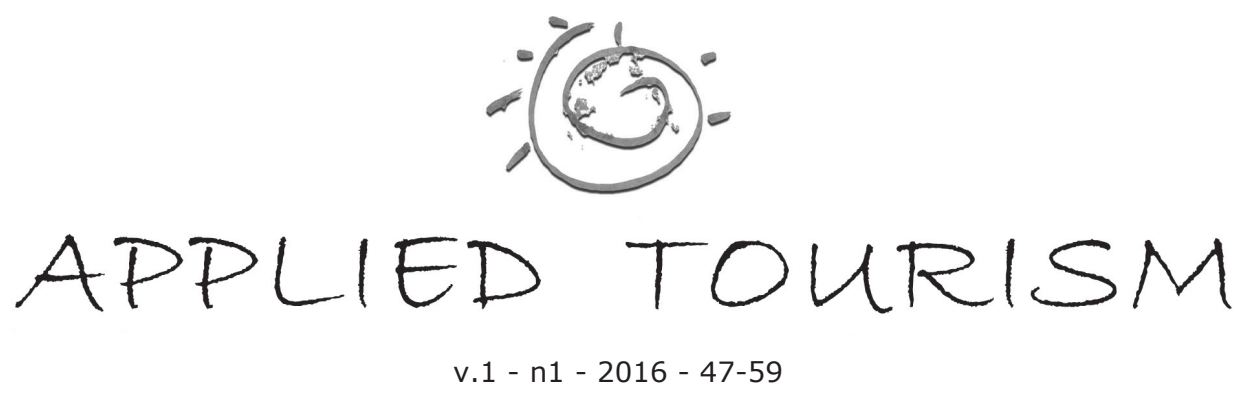

\title{
TURISMO DE NEGÓCIOS: UM ESTUDO DE CASO SOBRE A INFLUÊNCIA DO RESTAURANTE EM NEGÓCIOS INTERNACIONAIS
}

\section{BUSINESS TOURISM: A CASE STUDY ON THE INFLUENCE OF RESTAURANTS ON INTERNATIONAL BUSINESS MEETINGS}

\author{
Vinícius Val Gonçalves Cordeiro Fernandes - Mestre em Hospitalidade - Universidade Anhembi \\ Morumbi. E-mail: viniciusvalfernandes@yahoo.com.br \\ Cláudia Cristina Martins de Mello - Mestrae em Hospitalidade - Universidade Anhembi \\ Morumbi. E-mail: claudia_mello@uol.com.br
}

Andyara lena Paiva de Barros Camargo - Doutora em Ciências - Universidade de São Paulo

(USP). E-mail: andylena@usp.br

Recebido/Received: 17 setembro/september 2014. Aprovação/Approval: 18 janeiro/january 2015.

Resumo: O problema encontrado pelos autores apresentou-se na seguinte forma: A hospitalidade dos restaurantes influencia nas contratações de negócios internacionais? Partindo da referente pergunta, objetivou-se compreender a relevância da hospitalidade dos restaurantes na contratação de negócios envolvendo turistas internacionais. Também se entendeu necessário a compreensão de três objetivos específicos; Foi observada a importância da ambientação dos restaurantes, capacidade de adequação física e de cardápio por parte dos restaurantes e a viabilidade de atendentes que possam atender o turista em seu idioma natal. As hipóteses exploradas foram (H1) os restaurantes influenciam a favor da assinatura de negócios internacionais;
Abstract: The research topic raised by the authors tries to answer the following question: To what extent does the hospitality of restaurants influence the outcome of international business meetings?

Based on this matter, we aimed at understanding the importance of hospitality in restaurants regarding business involving foreign tourists. Three specific objectives were also considered significant to a better understanding: the importance of providing a suitable ambience; an adequate menu and physical structure; as well as the ability of restaurant attendants to speak diners' mother tongue. The hypotheses considered were the following: (H1) Restaurants 
(H2) os restaurantes não possuem relevância como local para negociações internacionais. $\mathrm{Na}$ coleta de dados foi feita uma pesquisa exploratória utilizando método de observação direto, um levantamento bibliográfico respaldado no protocolo de estudo de caso de Yin (2001), sendo também aplicadas entrevistas semiestruturadas. Foram obtidas respostas positivas à influência dos restaurantes, demonstrando a capacidade de atuação da comensalidade como fator de negociação entre os turistas de negócios. Outro importante dado observado foi o aumento de confiança proporcionado ao anfitrião quando este recebe seu convidado, no restaurante que costumeiramente frequenta.

Palavras-Chave: Turismo de Negócios; Gastronomia; Comensalidade; Hospitalidade;

\section{INTRODUÇÃO}

A atuação dos autores nas áreas de relações internacionais, bem como no setor gastronômico, influenciaram no desenvolvimento do problema de pesquisa e na escolha dos objetos de estudo. O problema decorreu devido à passada atuação de um dos autores como mediador de reuniões de negócios internacionais e se apresentou na pergunta: a hospitalidade dos restaurantes influencia nas contratações de negócios internacionais?

O estudo objetivou compreender a influência dos restaurantes nas negociações internacionais quando da vinda desses turistas. O turismo de negócios na cidade de São Paulo mereceu destaque no que tange à geração de crescimento econômico-financeiro não só para as instituições envolvidas, mas também para as regiões, países, blocos econômicos, além das futuras receitas, que poderiam ser auferidas por meio de outros setores do turismo. Como citado por Panosso (2008) o visitante de negócios também participa das estatísticas do setor de turismo, seu consumo de produtos e serviços o credencia como qualquer outro turista. O estudo também procurou compreender outros três objetivos específicos: a importância da ambientação dos restaurantes, a capacidade de adequação física ou de cardápio para o recebimento dos turistas e a viabilidade de um intérprete que possa atendê-lo em seu idioma natal.

Foi observada a simbologia que envolve a refeição em mesa compartilhada, bem como a hospitalidade praticada pelo anfitrião ao receber o hóspede. Canetti (1992) comenta positively influence the international business negotiations; ( $\mathrm{H} 2)$ Restaurants play no role and have no influence as a venue for international negotiations. Data were collected through an exploratory research using direct observation method; the literature review was based on Yin's (2001) case study methodology, and semi-structured interviews were also used. Affirmative answers were obtained on the influence of restaurants, showing their role in business tourists' negotiations. Another very important aspect observed was the boost in the hosts' confidence when receiving a guest in the restaurant they usually frequent.

Keywords: business tourism, gastronomy, commensality, hospitality

\section{INTRODUCTION}

The works of the authors in the area of international relations, as well as in the gastronomy industry, have exerted some influence on the development of the research topic and in the choice of the object of study. The topic was brought up due to the work of one of the authors as a mediator in international business meetings and took shape through a question: Does the hospitality of restaurants influence an international business meeting outcome? The study aimed at understanding the influence of restaurants in international negotiations, whenever foreign tourists participate. Business tourism in the city of São Paulo deserve to be highlighted due to its financial and economical relevance not only for the institutions involved, but also for the regions, countries and economical groups, in addition to the future revenue that may result from other businesses related to tourism. As mentioned by Panosso (2008) the business visitor also participates in the statistics in the tourism industry. Their consumption of products and services qualifies this tourist like any other. The study also aimed at analyzing some specific points: The importance of providing a suitable ambience; an adequate menu and physical structure; as well as the ability of restaurant attendants to speak the diners' native language.

The symbology that involves the meal at a shared table was observed, as well as the hospitality offered by the host. Canneti (1992) comments that, those who break bread together become companions (cum panem). Having a seat at a table is like being received in family. Social relations become closer when bread is broken together. 
que se tornam companheiros (cum panem) os que tomam o pão em comum. Sentar-se à mesa é como ser recebido em família, existe um estreitamento de relações sociais uma vez que uma refeição é compartilhada.

Como respostas ao problema foram trabalhadas duas hipóteses; (H1) os restaurantes influenciam e facilitam $\mathrm{O}$ fechamento de negócios internacionais; (H2) não há relevância dos restaurantes como local para fechamento de negócios internacionais. Neste contexto, 0 artigo analisou três restaurantes da cidade de São Paulo, reconhecidamente frequentados por executivos. O D.O.M., o restaurante Figueira Rubaiyat do Grupo Rubaiyat e o Gero pertencente ao Grupo Fasano.

Como metodologia, foi feita uma pesquisa exploratória de observação direta, seguido por um levantamento bibliográfico com a utilização do protocolo para estudo de caso de Yin (2005), também sendo feita a aplicação de entrevistas semiestruturadas.

\section{COMENSALIDADE NOS NEGÓcIOS}

A comensalidade tem como significado o ato de partilhar o alimento entre duas ou mais pessoas, no entanto ela não restringe a tão somente atender as necessidades fisiológicas de alimentação, tornando-se um fenômeno social. Os conceitos de simbologia ligados à comensalidade englobam representações éticas, religiosas, políticas e sociais, o que demonstra a quão aprofundada é sua influência, desde a sociedade pré-histórica até os dias contemporâneos. Cascudo (2004) afirma a importância da atividade comensal e comenta que a sociologia da alimentação decorre do próprio fundamento do ato social. Assim sendo, o homem anseia pelas refeições a serem realizadas em companhia de outro.

Um dos principais símbolos provenientes da comensalidade é a mesa, local de refeição, mediação da comunicação e negociação. Embora não fosse imprescindível para uma negociação, seu simbolismo como mediadora na procura de um acordo comum, a tornou uma facilitadora das inter-relações sociais.

Durante a maior parte da Idade Média a refeição e o banquete (convivium) constituam o mais eloquente símbolo de que se dispunha, para expressar o compromisso de manter relações baseadas na paz e na concórdia. A palavra chave nesse caso é
As possible answers to the problem two hypotheses were analyzed: (H1) Restaurants positively influence the international business negotiations; ( $\mathrm{H} 2)$ Restaurants play no role and have no influence as a venue for international business negotiations.

Within this context, this paper looks into three restaurants in São Paulo, renowned for being attended by business executives: D.O.M., Restaurante Figueira Rubayat, and Gero, a restaurant belonging to the Fasano Group.

As methodology, an exploratory research was conducted using a direct observation method, a literature review based on the Yin's (2005) case study methodology was made and semi-structured interviews were also applied.

\section{COMMENSALITY IN BUSINESS}

Commensality means sharing food between two or more people, however, it's not only about meeting nourishment needs. As it becomes a social phenomenon, the symbology concept related to commensality includes ethical, religious, political and social signification; which shows how deep it has influenced people from pre-history to present day. Cascudo (2004) states the importance of commensality and comments that sociology of food is a result of social relations. Therefore, people long for having meals with others.

The table is one of the main symbols originate from commensality, along with the venue for the meal, the communication and the negotiation itself. Although the meal is not indispensable for negotiations, its symbolism as a means of seeking a common ground - has made it a facilitator in social relations.

For most part of the Middle Ages the meal (convivium) was the most significant available symbol to express the commitment towards peace and concord. The key word within this context is "commitment", since eating and drinking together was a form of being obliged to meet certain conditions implied in this relation (Flandrin, 1998, p 300).

Yet, according to Flandrin (1998), such rites of commensality and its symbolism began to have a wider influence over society at a certain point in history. In the ancient Egypt, the plains of the Nile River, quite often flooded, yielded an abundance of cereals, such as barley, spelt and wheat, which supplied the domestic consumption and exports. The 
"compromisso", porque comer e beber junto eram uma forma de obrigar-se a satisfazer as condições que esse tipo de laço implica. ( FLANDRIN, 1998, p 300).

Ainda, segundo Flandrin (1998), tais ritos de comensalidade e sua simbologia também começaram a influenciar a sociedade. No Egito Antigo as planícies do Nilo, frequentemente inundadas, produziam uma abundante quantidade de cereais, como a cevada, a espelta e o trigo, estes abasteciam o consumo nacional e todo excedente era comercializado através da exportação. Romanos, um dos principais consumidores de cereais da época, frequentemente estabeleciam tratados comerciais com os egípcios. As discussões de troca de insumos e provisões ocorriam nas refeições providenciadas por uma das partes interessadas. $\mathrm{Na}$ mesa eram discutidos e estabelecidos os termos da troca, para que então o acordo fosse selado verbalmente. O organizador da refeição atuava como um anfitrião, que demonstrava toda sua hospitalidade oferecendo seus melhores produtos ao hóspede que acabara de chegar de viagem. A comensalidade agia então como negociador ao interesse comum.

\section{TURISMO DE NEGÓCIOS}

A compreensão da função de negociador por parte da comensalidade e a simbologia atrelada à mesa de refeição se mostraram ainda presentes e influentes no mundo dos negócios. A hospitalidade praticada com o turista à mesa o remete a um local seguro e de pertencimento, costumeiramente, fazendo com que este se sinta em casa, mesmo estando fisicamente distante de seu local de origem.

O turismo foi definido pela Organização Mundial do Turismo OMT (2001) como sendo "as atividades que as pessoas realizam durante viagens e estadas em lugares diferentes do seu entorno habitual, por um período inferior a um ano, com finalidade de lazer, negócios ou outras". Mário Beni comenta que o turismo está relacionado com as características do público, usufruindo o que o destino pode proporcionar de melhor e mais interessante "Deslocamento de executivos e homens de negócios, portanto turistas potenciais, que afluem aos grandes centros empresariais e cosmopolitas, a fim de efetuar transações e atividades profissionais, comerciais e industriais, empregando seu tempo livre no consumo de recreação e entretenimento típicos desses grandes centros, incluindo-
Romans, one of the biggest consumers at that time, frequently set up trade agreements with Egyptians. The discussions on the exchange of inputs took places in meals arranged by one of the parts. At the table, the exchange terms were discussed and established so that an agreement was verbally assumed. The organizer of the meals acted as a host who showed all his hospitality offering his very best to the guest that had just arrived from a long journey. Commensality then, acted as negotiator to a common interest.

\section{BUSINESS TOURISM}

The understanding of the negotiator's role from the commensality point of view and the symbolism of the table are still present and influential in the business world. The hospitality towards tourists at the table makes them feel safe and provides a certain sense of belonging, feeling like home.

Tourism has been defined by the UNWTO the United Nations World Tourism Organization (2001) as "the activities of persons travelling to and staying in places outside their usual environment for less than a year, for any main purpose such as leisure, business or other personal purpose". The main idea within the concept of tourism established by the UNWTO is related to the economical aspect, that is, a perspective focused on commercial, financial and normative issues. Burkart and Medik (1974) pointed out three fundamental reasons to define tourism: research purposes, statistics and legal/business management.

\begin{abstract}
Focusing on business tourism, Wada (2009) exemplify: The whole set of activities that result in travels under the responsibility of a legal entity - company, public department, union or NGOs - who pays for all the expenses foreseen in its travel policy, and responds for others aspects involved in the activity such as safety, the well-being of travelers, aiming at preserving the productivity while the person is out of his or her usual workplace (Wada, 2009, pp. 215).
\end{abstract}

When expenses are taken into account, it should be highlighted the safety, the timely and adequate provision of services and the health of the business tourist. This person will be, at times, in touch with cultures, customs, and concepts with which he is totally unfamiliar. As a consequence, the host must look after these matters, trying to mitigate or even eliminate possible problems. 
se também a freqüência a restaurantes com gastronomia típica e internacional" (BENI, 2002, p.423). A ideia central dentro do conceito de turismo estabelecido pela OMT é a questão econômica, ou seja, uma visão voltada para questões comerciais, financeiras, normativas. Para Burkart e Medlik (1974) são quatro os fatores fundamentais para se estabelecer uma definição de turismo: questões de estudo, estatística, legais/ gestão e empresariais.

Em vista de segmentação turismo de negócios pode ser compreendido como:

\begin{abstract}
o conjunto de atividades que resultam em viagens sob a responsabilidade de uma pessoa jurídica - empresa, órgão público, entidade de classe ou ONG - quem absorve todas as despesas previstas em sua política de viagem e se preocupa com outros aspectos como segurança, saúde e bem-estar do viajante, com intenção de garantir sua produtividade enquanto esteja fora de seu local habitual de trabalho (WADA, 2009, p 215).
\end{abstract}

Ao considerar as despesas que ocorrem, é necessário ressaltar a segurança, prestação de serviço adequado e em tempo hábil e a saúde do turista de negócio (executivo). Este, por vezes, estará em contato com uma cultura, costumes e conceitos que diferem de seu dia a dia, sendo assim o anfitrião deverá preocupar-se com a gestão de tais questões, tentando minimizar ou até erradicar os possíveis problemas.

$\mathrm{Na}$ tentativa de minimizar eventuais problemas atrelados ao turismo de negócio, torna-se viável a observação da Figura 1 (Etapas elementos e viabilizadores de viagens e negócios. Fonte: Segmentação do mercado turístico, 2009, p. 220).

A figura demonstra as etapas básicas para a viabilização de uma viagem de negócios em sua faixa superior; Elementos comuns na realização de tais viagens encontram-se no centro; Fatores relevantes, no entanto, dificilmente levados em conta na realização da viagem encontram-se na faixa inferior.

Torna-se possível observar a importância da infraestrutura, hospedagem, alimentação e ambiente de trabalho, oferecidos ao turista de negócios. Wada (2009) demonstra ainda uma visão aprimorada do setor, colocando o turista de negócios como fomentador e agente de iniciação, ampliação e aprimoramento das relações comerciais e não somente um consumidor de produtos e serviços que está em trânsito.
In the attempt of minimizing potential problems related to business tourism, it is important to analyze the following data (Figure 1: Stages, elements and business trip promoters. Source: Segmentação do Mercado turístico, 2009, p. 220).

This figure shows in its superior band the initial stages that make a business travel possible. Common elements in the making of a trip appear in the center; relevant factors however, hardly taken into account, are displayed in the lower band.

Thus, it is possible to observe the importance of infrastructure, accommodation, food and the work environment offered to the business tourist. Wada (2009) demonstrates also a sophisticated view of the sector, placing the business tourist as a promoter and agent in the beginning, amplification and improvement of commercial relations, not only a transient consumer of products and services. The responsibility for the traveler's health stands out when he is envisaged as a guest of the local host. The National Health Agency (Anvisa-2009) recommends a minimal checking on the history of establishments to be visited in order to ensure the well-being of the guest. Once the use of best practices and hygiene has been confirmed, and the existence of local licenses been checked, the place becomes eligible for the meeting.

The importance of gastronomy in tourism, according to Furtado (2004), lies in the fact that it is an opportunity to contact with the local products and culture. Nevertheless, some caution is required when indulging tourists with typical local dishes, a possible unfamiliarity of their body to certain ingredients in the composition should be considered. It is also necessary to take into account the environmental change the tourist has undergone, which may affect his metabolism and consequently, his state of mind.

\section{CHARACTERIZATION AND ANALYSIS OF THE RESTAURANTS}

According to the Ministry of Tourism (2013), São Paulo is the main business destination in the country. This data were obtained through the study of International Touristic demand. Based on these data, we chose as a goal, to study the restaurants of São Paulo, located in Jardins, a neighborhood close to Paulista Avenue, a central location and big business center. Each of them present 
É visível a necessidade de cuidados a serem levados com relação à saúde do viajante enquanto convidado do negociador local. A Agência Nacional de Vigilância Sanitária (ANVISA-2009) recomenda minimamente a vistoria do histórico dos estabelecimentos a serem visitados, assegurando assim a segurança e o bem-estar do hóspede. Uma vez confirmada a utilização das boas práticas de higiene e a presença da documentação necessária para o funcionamento de tal estabelecimento, ele torna-se elegível para o encontro.

A importância da gastronomia para o turismo segundo Furtado (2004) é o fato de esta proporcionar ao turista contato com a cultura e os produtos da localidade visitada. Contudo, a exposição do turista a um determinado prato típico deve ser regrada, em vista da possível falta de familiaridade de seu organismo para com os ingredientes que compõe o produto. Também é preciso observar a mudança de ambiente atravessada pelo turista, o que pode vir a afetar seu metabolismo e, consequentemente, sua disposição.

\section{CARACTERIZAÇÃO E ANÁLISE DOS RESTAURANTES}

Segundo o Ministério do Turismo (2013) São Paulo é o principal destino de turismo de negócio do país. Os dados foram encontrados por meio do Estudo da Demanda Turística Internacional. Com base nesses dados escolhemos para objetos de estudo restaurantes da cidade de São Paulo, localizados no bairro dos Jardins, região central próxima à Avenida Paulista - grande centro empresarial. Cada um deles apresenta diferentes tipologias, no entanto o alto padrão de serviços sendo um ponto em comum.

\section{D.O.M.}

O restaurante D.O.M. aclamado como um dosmelhoresdomundo (7a Colocadono World's 50 Best Restaurants de 2014) caracterizouse por sua cozinha contemporânea, de alto requinte e que tradicionalmente explora ingredientes nacionais como a pupunha, o jambu e a priprioca. Alex Atala, sócio proprietário e Chef do D.O.M. assume o papel de embaixador da gastronomia brasileira, o que se observou não só através dos pratos, mas também na ambientação do restaurante, adornado por uma temática brasileira, different typologies however, the very high standard of services is a common feature.

D.O.M.

Restaurant D.O.M. hailed as one of the world's best (7th place in the World's 50 Best Restaurants of 2014) has become famous for its contemporary cuisine, highly sophisticated and that traditionally explores national ingredients such as pupunha, jambu and priprioca. Alex Atala, partner and Chef at D.O.M. assumes the role of ambassador of the Brazilian gastronomy, which is easily noticed not only through the dishes he makes, but also in the restaurant's ambience, decorated with a Brazilian theme, resembling a study room with books, pictures and artifacts, all alluding to the Brazilian culture. When it comes to the potential of the place with the purpose of conducting international business, a large number of reservations were identified with the presence of foreign executives.

In almost all the cases these meetings were scheduled for lunch time on weekdays. In the lower hall the distance between lateral tables ranges from 1.5 to 2 meters. Central round tables are 2 to 2.5 meters apart from other tables, being more adequate for large executive groups.

However, the ambience that offers the most privacy is located in the upper hall, where a large and exclusive table awaits for meetings of any nature. Service was attentive, promptly responding to a request of putting two tables together and bringing more drinks. Besides Portuguese, the waiters showed to be ready to help tourists in English, French and Spanish. Menus were available in Portuguese, English and Spanish. Changes in the ingredients and the composition of dishes were also possible, highlighting the hospitability of the restaurant.

Figueira Rubaiyat

The name Rubaiyat originates from a series of poems by Omar Khayyan (1048 1131). In Persian, the word means "a fourline stanza ". As one of the Rubayat group, Figueira became famous for its quality meat, service and for the attractive presence of a 130 years old fig tree on its main hall. Besides the tree, the abundant natural light is another important feature. 
assemelhando-se até a uma sala de estudos com livros, fotos e artefatos que remetem à cultura nacional. Quanto à potencialidade do local como ambiente para fechamento de negócios internacionais, identificou-se um grande número de reservas executivas, com grande incidência de executivos estrangeiros.

Quase que em sua totalidade tais reuniões foram agendadas para o horário de almoço e durante os dias úteis. No salão inferior observou-se a variação de 1,5 a 2 metros de distância entre as mesas laterais. As mesas centrais circulares apresentaram um diâmetro livre maior ao seu redor, entre 2 e 2,5 metros, mostrando-se mais recomendáveis para a acomodação de grupos executivos. Contudo o ambiente mais privado situa-se no salão superior, onde foi encontrada uma espaçosa e exclusiva mesa fomentada para reuniões de todos os âmbitos.

$\mathrm{O}$ atendimento mostrou-se atencioso, pronto atendendo requerimentos como a junção de duas mesas e a reposição de bebidas. Os atendentes do salão mostraramse preparados para atender turistas do idioma inglês, francês e espanhol, além de todos aqueles que têm como idioma nativo o português. Foi observada a presença de cardápios em português, inglês e espanhol. Modificações nos ingredientes e construção dos pratos também se demonstraram possíveis, ressaltando a hospitalidade do restaurante.

Figueira Rubaiyat

O nome Rubaiyat provém de uma coleção de poemas de Omar Khayyan (1048 - 1131), em persa a palavra tem o significado de "quadra". Como um dos integrantes do grupo Rubaiyat, o Figueira é caracterizado pela qualidade de suas carnes, seu atendimento ao comensal e pela atraente presença de uma Figueira de 130 anos em seu salão principal. A ambientação oferece além da figura hospitaleira da Figueira, uma abundante luminosidade natural.

O farto e diversificado cardápio, tem como atrativo principal os cortes nobres bovinos, tornando o Figueira um atrativo para os apreciadores de carnes. A atenção no trato do produto, incluindo-se o ponto de cocção da carne, demonstra a preocupação da equipe em oferecer uma experiência gratificante para os comensais.

Grande capacidade para reservas executivas, considerando o amplo espaço físico
The generous and diversified menu has as its main attraction prime beef cuts which make Rubayat a preferred steakhouse. The especial and careful handling of meats, including its cooking point, demonstrates the staff concern in offering a gratifying experience to diners.

Large reservation capacity for executive meetings, considering an ample space that includes three halls. Distance between tables is 2 to 2.5 meters, with the possibility of changes as per request of diners in order to meet the needs of specific business meetings.

Even with a large number of tables to be served by the staff members, the service kept a good level of attentiveness. The politeness of the staff is remarkable and easily seen in the fact that they try not to interrupt clients' conversations. Changes in the menu are very welcome and once required by the diner, the staff pays close attention to make sure everything goes accordingly. Menus were available in Portuguese, English and staff member were capable of communicating in English and Spanish.

Gero

Restaurant Gero, as a member of the Fasano Group, stands out for first class ingredients and classic Italian cuisine dishes, such as pasta, risotto, meat and fish. After the inauguration in 1994, it quickly became a gastronomic reference in São Paulo, with the concept of offering an ambience less formal than the sophisticated Fasano. The idea pleased several new diners, as well as loyal old time customers who have found at Gero a less luxurious place without forsaking the quality in service and food. Foreign executives were frequent to the place, including bookings of meetings at lunch time.

The sober and discrete ambience provides ideally the needed tranquility for conducting business. Tables placed 1.8 to 2 meters apart may be relocated in order to best serve the clients. The staff is efficient and friendly. Each waiter serves a small number of tables, easing the communication between diners and their attendants. Some waiters are capable of communicating in English, Spanish and Italian. In addition to Portuguese, the menu is also displayed in English and Italian. Adaptations due to dietary restrictions or by simple request are all possible. 
que engloba os três salões, as mesas possuem entre 2 e 2,5 metros de distanciamento em sua disposição, caso requerido pelo cliente podem ser feitas adequações específicas para reuniões de negócios.

Mesmo com o grande número de mesas a serem atendidas por cada um dos membros do salão, foi observado um atendimento atencioso. O tato apresentado pela equipe surpreende, já que esta procura evitar interrupções nas conversas de seus clientes. Adaptações no cardápio são muito bem atendidas e uma vez que requisitadas pelo comensal, o staff se mostra atento para que não ocorra nenhum comprometimento ao prato especificado.

Foi observada a presença de cardápios em português e inglês, assim como atendentes capacitados a se comunicarem nas línguas inglesa e espanhola.

\section{Gero}

O restaurante Gero como integrante do grupo Fasano, prima por ingredientes de excelência e por pratos clássicos da culinária italiana, tais como massas, risotos, carnes e peixes. Após seu surgimento em 1994, tornou-se rapidamente um marco gastronômico da capital paulista, trazendo o conceito de criar um ambiente mais informal do que o sofisticado Hotel Fasano, a ideia foi de agrado de diversos novos comensais, bem como antigos habitués, que enxergaram no Gero um ambiente despojado, sem a perda de qualidade no atendimento e na comida.

Foi verificada uma grande frequência de executivos estrangeiros, inclusos agendamentos para reuniões no horário de almoço. O ambiente sóbrio e discreto, proporciona idealmente a tranquilidade necessária pra o fechamento de negócios. As mesas dispostas com 1,8 e 2 metros de distância entre si podem ser realocadas, visando uma melhor recepção do cliente.

A equipe de salão se mostra eficaz e cordial, cada garçom se limita ao atendimento de um pequeno número de mesas, facilitando a comunicação dos comensais para com seu atendente. Alguns dos membros do salão se mostram capacitados a comunicar-se em inglês, espanhol e italiano.

Afora português o cardápio pode ser encontrado também em inglês e italiano. Adaptações devido a restrições alimentares ou

\section{DATA ANALYSIS}

In order to make easier to visualize and compare data, a table (Table of Interviews. Source: Direct observation by the authors, 2014) including the main features observed in each restaurant follows below.

Based on the collected data, the researchers consider that doing business in restaurants is a common practice and that restaurants play a relevant role in this matter. The ambience offers diners a safe location and makes them more comfortable when conducting business.

The hospitality of restaurants towards the foreign visitor is of paramount importance. This has been observed in such aspects as the menu written in other languages and the staff preparation to communicate with foreign tourists, showing the awareness that as a host, the restaurant must adapt itself to provide the best service to guests. This welcoming environment creates an atmosphere in which the tourist feels safe and relaxed, striping himself of a certain rigor thus adopting a more adequate attitude towards negotiation. The host should also take into account his or her own well-being when searching for the most suitable ambience.

Thus, the host's preference directs him to places he considers comfort zones and, by doing so, increases his self-esteem due to the fact that he knows the venue where business will take place. Therefore, it was observed that business executives visit the same restaurant even when their business counterparts are different in each occasion.

Consequently, the $\mathrm{H} 1$ hypothesis applies to the study, which affirms the existence of a positive influence of restaurants on the successful conclusion of international business.

\section{FINAL CONSIDERATIONS}

The authors aimed at understanding the influence of restaurants on negotiations related to international business tourism, as well as observing the ambiance of restaurants, the capability of adapting the lounge and the menu to better receive visitors and the aptitude of staff members to communicate with visitors in several languages.

Commensality has always performed the function of social linkage. Its application as negotiator is the best example of its influence in human relations. The vulnerability or hostility 
mesmo atendendo o requerimento de clientes são viáveis.

\section{ANÁLISE DE DADOS}

De modo a facilitar a visualização e comparação de dados, foi criada uma tabela Tabela de entrevistas. Observação direta por parte dos autores, 2014) incluindo as principais observações feitas em cada um dos restaurantes.

A partir dos dados coletados os pesquisadores compreendem que o tratamento de negócios internacionais nos restaurantes é frequente e que 0 restaurante possui papel relevante. A ambientação remete os comensais a um local seguro, consequentemente tornando-os mais a vontade para lidar com seus tratados comerciais.

A receptividade do restaurante para com o visitante estrangeiro é de crucial importância. Isto foi observado através da presença de cardápios em outras línguas, bem como o preparo da equipe de salão para comunicar-se em outra língua, demonstrando a consciência de que como anfitrião, o restaurante se adéqua da melhor maneira para receber seu hóspede. Esta ambientação transmite a sensação de segurança para o turista, que desarma-se de uma possível sisudez e adota uma postura mais suscetível à negociações.

O anfitrião em sua procura pelo ambiente adequado, também deve se preocupar com o seu bem estar. Sendo assim, sua preferência o remete a locais os quais ele considera como zonas de conforto e que poderão aumentar sua autoestima devido ao ambiente familiarizado no qual a negociação se realizará. Por esta razão foi possível observar executivos que frequentemente visitam o mesmo restaurante para uma reunião de negócios, ainda que os turistas de negócios que o acompanhem sejam diferentes em cada ocasião.

Desta maneira foi compreendido como aplicável a (H1) hipótese que afirma a existência de uma influência positiva dos restaurantes na assinatura de negócios internacionais.

\section{CONSIDERAÇÕES FINAIS}

Os autores objetivaram compreender a influência dos restaurantes nas negociações internacionais no turismo de negócios, bem como tendo em seus objetivos específicos of man can be erased during the meal. The pleasures of the meal and of the conversation take over diners. Thus, negotiations in which the parts have come with pre-established judgments and precautions, give place to an open and unique environment for a clear and objective discussion desired by both parts.

The business tourist has a special concern about his safety whenever he travels. It is not only about his personal belongings, but also about his health and well-being. Thus, the dietary food safety of these visitors must be taken into account by the host, as well as by the restaurants to be visited. It is important to highlight that any damage to the tourist's health might jeopardize the successful outcome of the business. The tranquility of a good meal and the feeling of being well assisted reinforce the visitor's sensation of safety.

A sense of belonging arises when the tourist come across an attendant with whom he can communicate fluently in his native language. It is in this ambience that he finds himself ready to deal with business negotiations in the best possible way.

Therefore, it was possible to understand that the (H1) hypothesis, which pointed out to the relevance of restaurants over the successful conclusion of business is real and can be applied. Nevertheless, due to the limited number of elements analyzed, further and deeper research is required in order to a more general assessment.

\section{REFERENCES}

Albrecht, K. (1995). Agregando valor à negociação. São Paulo, SP: Makron Books.

ANVISA Data (2009). Retrieved from: http://portal.anvisa.gov.br/wps/wcm/ connect/28fe0e0049af6b5b96e1b$66 \mathrm{dcbd} 9 \mathrm{c} 63 \mathrm{c} / 2 \mathrm{Documentobasepa-}$ raGuiasdeBoasPraticasNutricionais2.pdf?$M O D=A J P E R E S$

Beni, M. (2001) Análise estrutural do Turismo. São Paulo, SP: Senac.

Burkart, A. J. \& Medlik, S. (1974) Tourism: Past, Present and Future. Oxford OXON: Heinemann.

Canetti, E. \& Maurice B. (1992) Pour une sociologie de la transaction Sociale. Paris, IF: L'Harmattan.

Cascudo, L. C. (2004) História da Alimentação no Brasil. (3a.ed.) São Paulo, SP: Global. 
observar a ambientação dos restaurantes, capacidade de adequação do salão e do cardápio para melhor receber os visitantes e viabilidade de atendentes que possam comunicar-se com os visitantes em línguas estrangeiras.

A comensalidade sempre desempenhou a função de laço social, sua aplicação como negociadora é o maior exemplo de sua influência nas relações humanas. A vulnerabilidade ou hostilidade do homem podem ser apagadas durante $\mathrm{o}$ ato da refeição, este se deixa dominar pelo prazer do alimento e pela conversa oferecida por seu companheiro de mesa. De tal maneira, negociações nas quais as partes se encontram munidas por receios ou ideias pré-estabelecidas, encontram na simbologia da mesa um ambiente único para a discussão clara e direta dos objetivos almejados por cada uma das partes.

O turista de negócios quando em viagem tem como uma de suas prioridades a segurança. Não se tratando somente de bens materiais, bem como de sua saúde e seu bem estar. Sendo assim a segurança alimentar destes visitantes, deve ser levada em consideração pelo anfitrião que os recebe, bem como pelos restaurantes que serão visitados. Deve ser observado que um comprometimento da saúde do turista, poderá desencadear em um movimento contra a firmação do negócio proposto.

A tranquilidade de uma boa refeição e de sentir-se bem atendido durante ela enaltece a sensação de segurança do visitante. Existe a clara sensação de pertencimento, uma vez que o turista encontra em um dos atendentes uma pessoa com quem possa se comunicar em uma de suas línguas fluentes. É situado neste ambiente que ele então se encontra pronto para melhor lidar com seus acordos e tratados.

Portanto foi possível compreender que a (H1) hipótese que apontava para os restaurantes como ponto de relevância favorável para o fechamento de negócios internacionais se mostrou aplicável. No entanto devido ao limitado número de objetos estudados, se faz necessário um aprofundamento de estudos, a fim de efetuar uma avaliação geral.

\section{REFERÊNCIAS BIBLIOGRÁFICAS}

Albrecht, K. (1995). Agregando valor à negociação. São Paulo, SP: Makron Books. ANVISA Data (2009). Disponível em: http://
Furtado, F. L. (2004) A Gastronomia como Produto Turístico. Revista Turismo.

Grupo Rubaiyat (n.d.) Retrieved from: http:// www.rubaiyat.com.br/historia-do-gruporubaiyat.

Guia Time Out - IG (n.d.) Retrieved from: http://www.timeout.com.br/sao-paulo/ restaurantes/venues/589/a-figueirarubayat.

Guia Veja São Paulo Comer e Beber 2013/2014 (2013, April 23). São Paulo, SP: Editora Abril.

Lashley, C. \& Morrison, A. (2004) Em busca da hospitalidade-perspectiva para um mundo globalizado. Barueri, SP: Editora Manole.

Ministry of Tourism Data (2013). Retrieved from: http://www.turismo.gov.br/turismo/ noticias/todas_noticias/20130902-1.html

Montanari, M. \& Flandrin, J. L. (1998). História da alimentação. (2a. Ed.) São Paulo, SP: Estação Liberdade.

Panosso, A. \& Lohmann, G. (2008). Teoria do turismo. São Paulo, SP: Editora Aleph.

Restaurante D.O.M. (n.d.) Retrieved from: http://domrestaurante.com.br/pt-br/ sobre.html.

Restaurante Gero (n.d.) Retrieved from: http://www.fasano.com.br/gastronomia/ restaurante/18.

AZAMBUJA, M. A gastronomia como produto turístico. Retrieved from: http:// www.revistaturismo.com.br/artigos/ gastronomia.html

Wada, E. K. (2009). Turismo de negócios: viagens corporativas, eventos e incentivo. In Panosso, A. e Ansarah, M. G. R. (Eds.) Segmentação do mercado turístico. (pp. 220) Barueri, SP: Editora Manole.

Wada, E. K. (2009). Turismo de negócios: viagens corporativas, eventos e incentivo. In Panosso, A. e Ansarah, M. G. R. (Eds.) Segmentação do mercado turístico. (pp. 213-225) Barueri, SP: Editora Manole.

Yin, R. K. (2005) Estudo de Caso: Planejamento e Métodos. ( $\left.2^{\mathrm{a}} \mathrm{Ed}\right)$. Porto Alegre, RS: Editora Bookman. 
portal.anvisa.gov.br/wps/wcm/connect/ 28fe0e0049af6b5b96e1b66dcbd9c63c/2DocumentobaseparaGuiasdeBoasPraticasNutricio-

nais2.pdf?MOD $=$ AJPERES

Beni, M. (2001) Análise estrutural do Turismo. São Paulo, SP: Senac.

Burkart, A. J. \& Medlik, S. (1974) Tourism: Past, Present and Future. Oxford OXON: Heinemann.

Canetti, E. \& Maurice B. (1992) Pour une sociologie de la transaction Sociale. Paris, IF: L'Harmattan.

Cascudo, L. C. (2004) História da Alimentação no Brasil. (3a.ed.) São Paulo, SP: Global.

Furtado, F. L. (2004) A Gastronomia como Produto Turístico. Revista Turismo. Disponível em: http://www.revistaturismo. com.br/artigos/gastronomia.html.

Grupo Rubaiyat (n.d.). Disponível em: http:// www. rubaiyat.com.br/historia-do-gruporubaiyat.

Guia Time Out - IG (n.d.). Disponível em: http://www.timeout.com.br/sao-paulo/ restaurantes/venues/589/a-figueirarubayat.

Guia Veja São Paulo Comer e Beber 2013/2014 (2013, April 23). São Paulo, SP: Editora Abril.

Lashley, C. \& Morrison, A. (2004) Em busca da hospitalidade-perspectiva para um mundo globalizado. Barueri, SP: Editora Manole.

Ministério do Turismo (2013). Disponível em: http://www.turismo.gov.br/turismo/ noticias/todas_noticias/20130902-1.html

Montanari, M. \& Flandrin, J. L. (1998). História da alimentação. (2a. Ed.) São Paulo, SP: Estação Liberdade.

Panosso, A. \& Lohmann, G. (2008). Teoria do turismo. São Paulo, SP: Editora Aleph.

Restaurante D.O.M. (n.d.). Disponível em: http://domrestaurante.com.br/pt-br/ sobre.html.

Restaurante Gero (n.d.). Disponível em: http://www.fasano.com.br/gastronomia/ restaurante/18.

AZAMBUJA, M. A gastronomia como produto turístico. Disponível em: http:// www.revistaturismo.com.br/artigos/ gastronomia.html

Wada, E. K. (2009). Turismo de negócios: viagens corporativas, eventos e incentivo. In Panosso, A. e Ansarah, M. G. R. (Eds.) Segmentação do mercado turístico. (pp. 213-225) Barueri, SP: Editora Manole.

Yin, R. K. (2005) Estudo de Caso: Planejamento e Métodos. ( $\left.2^{\mathrm{a}} \mathrm{Ed}\right)$. Porto Alegre, RS: Editora Bookman. 
Vol. 1 - n. 1 - 2016

\section{Attachments}

\begin{tabular}{|c|c|c|c|}
\hline & DOM & FIGUEIRA RUBAYIT & GERO \\
\hline $\begin{array}{l}\text { Presença de executivos } \\
\text { estrangeiros }\end{array}$ & $\begin{array}{l}\text { Sim. Durante todos os } \\
\text { dias úteis da semana }\end{array}$ & $\begin{array}{l}\text { Sim. Durante todos os } \\
\text { dias úteis da semana }\end{array}$ & $\begin{array}{l}\text { Sim. Durante todos } \\
\text { os dias úteis da } \\
\text { semana }\end{array}$ \\
\hline Reuniões executivas & $\begin{array}{l}\text { Sim. Durante todos os } \\
\text { dias úteis da semana }\end{array}$ & $\begin{array}{l}\text { Sim. Durante todos os } \\
\text { dias úteis da semana }\end{array}$ & $\begin{array}{l}\text { Sim. Durante todos } \\
\text { os dias úteis da } \\
\text { semana }\end{array}$ \\
\hline Distancia de mesas & \begin{tabular}{|c|} 
Mesas laterais 1,5 a 2 \\
metros. Mesas circulares \\
2 a 2,5 metros
\end{tabular} & 2 metros & 1,8 a 2 metros \\
\hline $\begin{array}{l}\text { Presença de cardápios em } \\
\text { outros idiomas? Quais? }\end{array}$ & Sim. Inglês e espanhol & Sim. Inglês & Sim. Inglês e italiano \\
\hline $\begin{array}{l}\text { Número de } \\
\text { mesas atendidas } \\
\text { simultaneamente por } \\
\text { garçons }\end{array}$ & Uma & De três a cinco & Duas a três \\
\hline $\begin{array}{l}\text { Membros do staff fluentes } \\
\text { em outros idiomas? Quais? }\end{array}$ & $\begin{array}{c}\text { Sim. Hostess, Sommalier } \\
\text { e Maitrê. Francês, } \\
\text { espanhol e italiano. }\end{array}$ & $\begin{array}{c}\text { Sim. Hostess, Sommalier } \\
\text { e Maitrê. Inglês e } \\
\text { espanhol. }\end{array}$ & $\begin{array}{c}\text { Sim. Hostess, } \\
\text { Sommalier e Maitrê. } \\
\begin{array}{c}\text { Francês, espanhol e } \\
\text { italiano. }\end{array} \\
\end{array}$ \\
\hline $\begin{array}{l}\text { Possibilidade de alteração } \\
\text { nos pratos quando } \\
\text { requerido por clientes }\end{array}$ & $\begin{array}{l}\text { Sim. Atendendo } \\
\text { restrições alimentares } \\
\text { ou por opção do } \\
\text { comensal }\end{array}$ & \begin{tabular}{|l} 
Sim. Atendendo \\
restrições alimentares ou \\
por opção do comensal
\end{tabular} & $\begin{array}{c}\text { Sim. Atendendo } \\
\text { restrições } \\
\text { alimentares ou por } \\
\text { opção do comensal }\end{array}$ \\
\hline
\end{tabular}

\begin{tabular}{|c|c|c|c|}
\hline & DOM & Figueira Rubayat & Gero \\
\hline $\begin{array}{l}\text { Presence of foreign } \\
\text { executives }\end{array}$ & $\begin{array}{c}\text { Yes } \\
\text { every working day }\end{array}$ & $\begin{array}{c}\text { Yes } \\
\text { every working day }\end{array}$ & $\begin{array}{c}\text { Yes } \\
\text { every working day }\end{array}$ \\
\hline Business Meetings & $\begin{array}{c}\text { Yes } \\
\text { every working day }\end{array}$ & $\begin{array}{c}\text { Yes } \\
\text { every working day }\end{array}$ & $\begin{array}{c}\text { Yes } \\
\text { every working day }\end{array}$ \\
\hline Distance between tables & $\begin{array}{c}\text { Lateral table }-1.5 \text { to } 2 \\
\text { meters, round tables }-2 \\
\text { to } 2.5 \text { meters }\end{array}$ & 2 meters & 1.8 to 2 meters \\
\hline \begin{tabular}{|l|} 
Presence of menus in \\
others languages? Which?
\end{tabular} & Yes, English and Spanish & Yes, English & $\begin{array}{l}\text { Yes, English and } \\
\text { Italian }\end{array}$ \\
\hline $\begin{array}{l}\text { Number of tables attended } \\
\text { simultaneously by waiters }\end{array}$ & One & Three to five & Two to three \\
\hline $\begin{array}{l}\text { Staff members fluent in } \\
\text { other languages? Which? }\end{array}$ & $\begin{array}{c}\text { Yes, hostess, sommelier } \\
\text { and Maitre - English, } \\
\text { French, Spanish and } \\
\text { Italian }\end{array}$ & $\begin{array}{c}\text { Yes, hostess, sommelier } \\
\text { and Maitre - Spanish } \\
\text { and English }\end{array}$ & $\begin{array}{c}\text { Yes, hostess, } \\
\text { sommelier and Maitre } \\
\text { - English, Spanish } \\
\text { and Italian }\end{array}$ \\
\hline $\begin{array}{l}\text { Possibility of changes in } \\
\text { dishes when required by } \\
\text { customers }\end{array}$ & $\begin{array}{l}\text { Yes, complying with } \\
\text { dietary restrictions or } \\
\text { per request }\end{array}$ & $\begin{array}{l}\text { Yes, complying with } \\
\text { dietary restrictions or } \\
\text { per request }\end{array}$ & $\begin{array}{c}\text { Yes, complying with } \\
\text { dietary restrictions or } \\
\text { per request }\end{array}$ \\
\hline
\end{tabular}




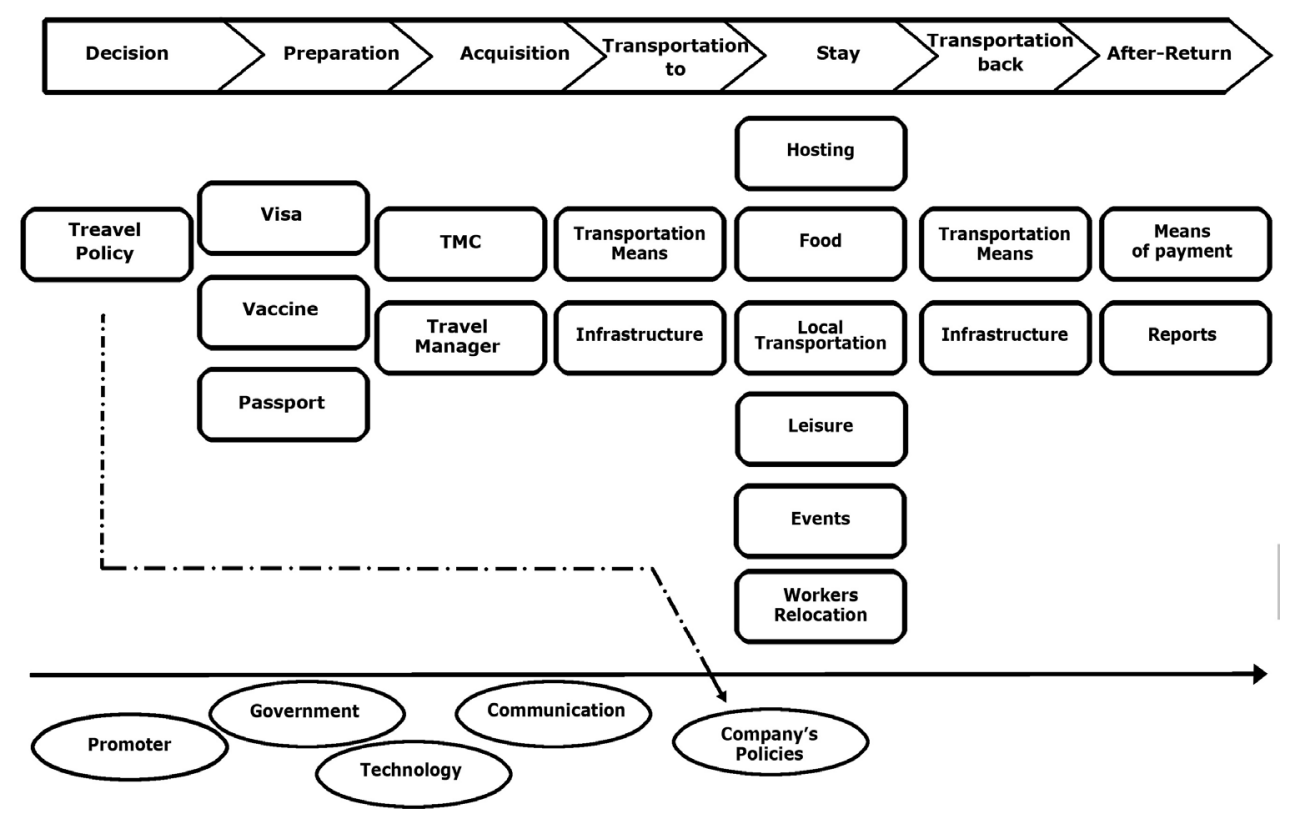

